\title{
Three Faiths, Two Continents, One Island: Creating the Dances of São Tomé
}

\author{
Robert Garfield \\ Department of History, DePaul University, United States
}

Copyright $\bigcirc 2017$ by authors, all rights reserved. Authors agree that this article remains permanently open access under the terms of the Creative Commons Attribution License 4.0 International License

\begin{abstract}
The island of São Tomé, located in the Gulf of Guinea off the west-central coast of Africa, has been the site of a broad cultural syncretism, especially regarding dance. The dances of São Tomé are a mixture of European. African and Jewish roots are unique to the island. The major dance forms are known as Tchiloli, Danço Congo, and Sócópé [or Ussua]. This paper traces the settlement of São Tomé by Portuguese (mostly the unwanted of Lisbon), Jewish exiles, and African slaves. Each group brought its own cultural practices to the island, where they blended in the small, isolated environment, and continued to evolve over the centuries, eventually incorporating 20th/21st Century costuming, instruments and movement.
\end{abstract}

Keywords São Tomé, Dances, Judaism, African Culture, History

\section{Introduction}

It sounds like a joke: "what do you get if you mix European, African and Jewish culture on a remote island?" The answer, however, is no joke; instead, what you get is an unusual and unique cultural creation. For nearly 500 years, these elements mingled, mixed and interacted on a distant island, and produced, among other things, a set of dances found nowhere else in the world, but whose roots can be traced back to three religious traditions and two continents.

\section{Settlement}

The island of São Tomé lies in the Gulf of Guinea, about 120 miles off the west-central coast of Africa. [Figure 1] It is one of the four islands of the Gulf, the others being Fernando Pó (today called Biyago), Príncipe and Ánnobon. Save for Fernando Pó, none were inhabited when found by Europeans, a fact that helped determine their history and the mixing of peoples and cultures. The Portuguese discovered São Tomé in December 1471; early visitors noted the enormous tropical fertility of the island, which lies just north of the Equator, and the Portuguese Crown decided that bringing the island under cultivation could prove profitable, both to the Royal Treasury and to the ongoing voyages seeking a sea route to India. [1]

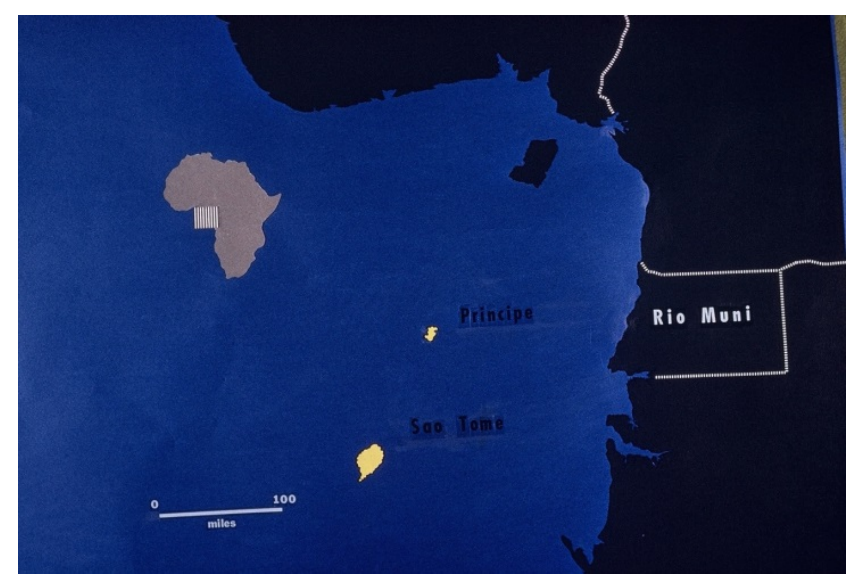

Figure 1. São Tomé in the Gulf of Guinea, showing its relationship to the African mainland and to its sister islands of Príncipe and Fernando Pó. The smallest island, Ánnobon, is off the map to the southwest [lower left], about 150 miles from SãoTomé.

By the 1510 s, it was clear that sugar would be by far the most profitable crop, with an almost limitless market in Europe, one that the reigning major supplier, the island of Madéira, could not satisfy.[2] The problem was not the crop, but the labor needed to grow, harvest, and process it. Sugar was, and is, very labor-intensive and is best grown as a plantation crop. In the early 16 th century, this meant slaves; and in the geographical context of São Tomé, this meant slaves from the nearby African mainland, especially from the recently-contacted Kingdom of Congo, in what is today northern Angola. In less than a decade, an enormous slave-trade grew up, with tens of thousands of Africans being brought to the island to labor on the newly-established sugar plantations, while thousands of others were "seasoned" on the island before being shipped across the Atlantic to the equally new plantations in the West Indies and on the 


\section{American mainland.[3]}

However, the Portuguese Crown wanted more than just slaves on the island. A large European population was felt to be equally necessary to the island's economic success and political stability. Unfortunately, few Portuguese could be persuaded to go there. The island was far away and had already acquired a well-founded reputation as a graveyard for Europeans. To remedy this, the Portuguese resorted to methods only slightly less coercive than the acquisition of Congolese slaves. The jails of Lisbon were emptied, debtors, and undesirables (especially prostitutes) swept off the streets, and all were ordered sent to São Tomé on some quasi-legal pretext. Most startlingly, the Portuguese decided to seize the children of the many Jews in Portugal, convert them to Catholicism, give them to the "families" created by the rounding-up of the unwanted, and send the whole lot down to São Tomé.[4] In fact, the Jewish children probably outnumbered all of the other White exiles.

Besides a large population of native Jews, Portugal had just experienced a huge influx of Spanish Jews fleeing the expulsion of March 1492. To the Portuguese, reducing the number of non-Catholics, saving young souls, and populating a distant but potentially very profitable island could all be accomplished by the same expedient. Thus, undesirable Whites, even more undesirable Jews, and Africans, could all be sent to create a society, and a labor force, where none had existed before. A handful of Portuguese administrators, both civil and ecclesiastical, were sent to keep some sort of control over this racial and cultural hodge-podge, but for the most part the new São Toméans were left to work out their relationships by themselves.

Many of the original African inhabitants eventually won their freedom, and soon became the effective ruling class of São Tomé. They owned the sugar plantations, controlled the Senádo da Cámara, or local council, and by force and/or bribery usually bent the Portuguese royal government to their will, when they did not simply ignore it. (This was helped by the fact that the local climate was deadly to newcomers, especially Europeans. Governors, bishops and bureaucrats usually did not live long enough to take effective actions against the planters' political and economic machinations). Most of these early planters were Afro-European, since the Portuguese held few prejudices against miscegenation; indeed, it was encouraged in order to build up the local population as quickly as possible. [5]

It might also be said that the population was in some ways Afro-Jewish. While Judaism as a practiced faith quickly disappeared from São Tomé, some Jewish cultural beliefs and practices survived among a population that was officially Catholic and ethnically mostly African. This would reappear in the island's history and would connect with the unique folk-dance traditions of São Tomé.

The dominant Afro/Portuguese/Jewish elite continued to import slaves to the island, and these brought with them cultural artifacts, especially music and dance, from their former homes on the African mainland. These would combine with the European culture of the first settlers, the result being the island's peculiar and place-specific dance and music traditions.

One of the most startling effects of such mixing came in the early 17th century. The Catholic Church on São Tomé was forever on the lookout for residual Judaism, knowing what the origin of so many islanders had been. In 1616, a new bishop, Pedro da Cunha Lobo, had come to the island. One night in October 1621, he was awakened by the sounds of a celebration just outside his residence. Looking out his window, he claimed to see a procession of "Jews" who were dancing, singing and parading around a "golden calf." Disgusted, the bishop took the first ship back to Portugal. (He never made it, dying in a shipwreck on the way). [6]

Cunha Lobo, on the lookout for Jews, saw what he expected to see, a Jewish celebration. What he almost certainly saw was a number of São Toméans performing one of the unique local dances of the island, one which may indeed have incorporated some vaguely-remembered Jewish elements. (The whole scene sounds like a Simchas Torah -"rejoicing of the Law" -- celebration, the annual ritual that marks the completion of the reading of the Torah and the beginning of its being read again.) Based on the very limited references and descriptions that have survived, it is likely that what the Bishop saw was a performance of Tchíloli, the most widely-performed, most syncretic and probably the oldest of the island's unique dances. As such, it would incorporate more disparate elements than other celebrations.

It is also the loudest and most colorful, waking the bishop up in the night and exposing him to music and dance that might have seemed at least vaguely familiar; Jews were officially gone from Portugal, but Jewish-derived cultural manifestations were certainly not. How a "golden calf" got into the act, literally, is a mystery, since such idols were specifically rejected by Judaism. Most likely, Bishop Cunha Lobo had only the vaguest knowledge of the Old Testament and of Judaism, and confused an African-derived celebratory object used during the festival with the ancient reference from the Bible. It is in this somewhat bizarre incident that the folk culture of São Tomé most clearly emerges into and connects with conventional history.

\section{The Dances}

The folk dances [7] of São Tomé, which figured in the flight of Bishop Cunha Lobo, are unique to the island. Each small island village [Figure 2] has its own dance group, voluntary, and supported solely by the respective villages. Occasional performances for various local ceremonies can be held at any time, but it is customary to hold island-wide festivities, which are in the nature of a competition, in August or September of each year. Today, the performances are held in the soccer stadium in São Tomé City, but in former times any large open venue would do. The market place in the City, or the square in front of the Cathedral, 
[Figure 3] would be most often used for these performances. If the latter, it is no wonder that Bishop Cunha Lobo was awakened during the night.

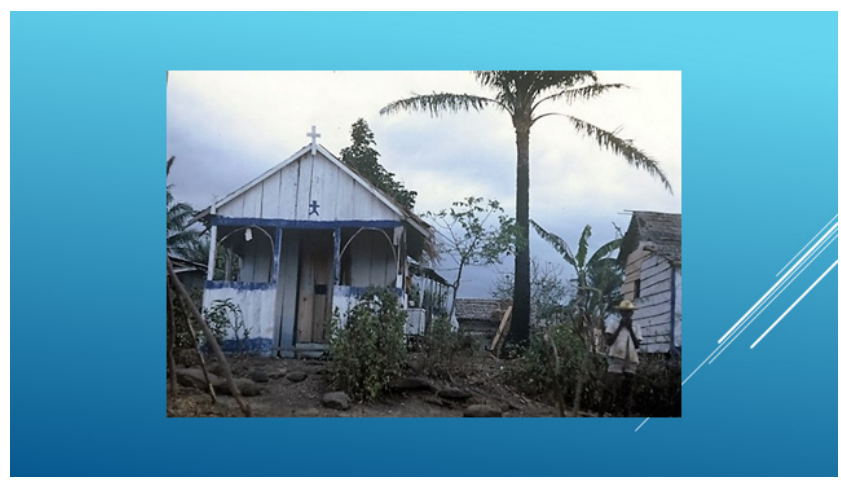

Figure 2. A typical poor village in contemporary São Tomé: Any open area in the village could have been used for a performance of one of the island's dances.

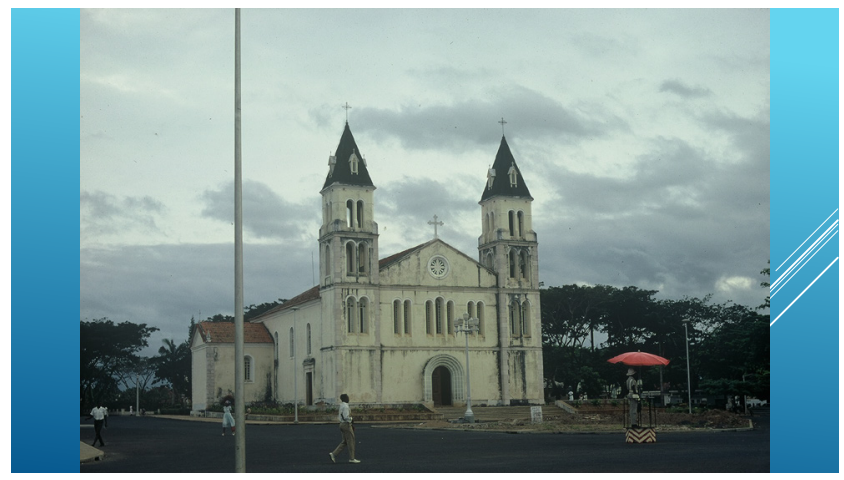

Figure 3. The Cathedral of São Tomé as it appears today. The current cathedral was built in 1834 on the site of the original. It would have been about here that bishop Lobo saw the "Jewish" procession.

Each village's group is costumed in brilliant and original dress, which is often different for each settlement and which is often changed, though not necessarily on an annual basis. Flags and banners of various kinds are also a part of a group's regalia. Music is provided by a band playing African-derived instruments, mostly variants of drums, other percussion instruments, and simple stringed instruments. [Figure 4] In recent years, European instruments, such as flutes and guitars, have become more common. The repertoire of each village group can take from two to six hours to perform, but entire shows are usually put on only by an individual village at its own particular festival. For the island-wide performances, each village is usually limited to between one and two hours for its presentation; nevertheless, the festival may last several days.

The dances are of mixed African and European derivation both in significance and in style of performance. Though based on centuries'-old traditions, the dances have been culturally updated in presentation; for example, historical characters are now seen using cell-phones, wearing wrist-watches, carrying attaché cases and sporting sunglasses! Equally, parts of the performance may be gradually dropped over the decades or centuries; thus, any "Jewish" remnants in the music and dancing would have been lost long ago. [Figure 5]

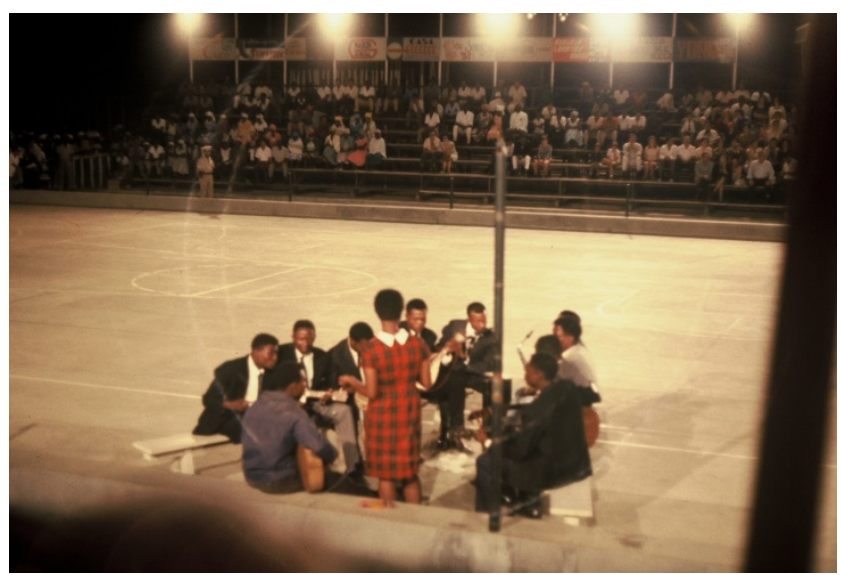

Figure 4. A band prepares for a Tchiloli performance. Modern dress and modern instruments are often found today for such performances, especially when it is an ad hoc one not held at the usual time, in August or September, for an island-wide competition.

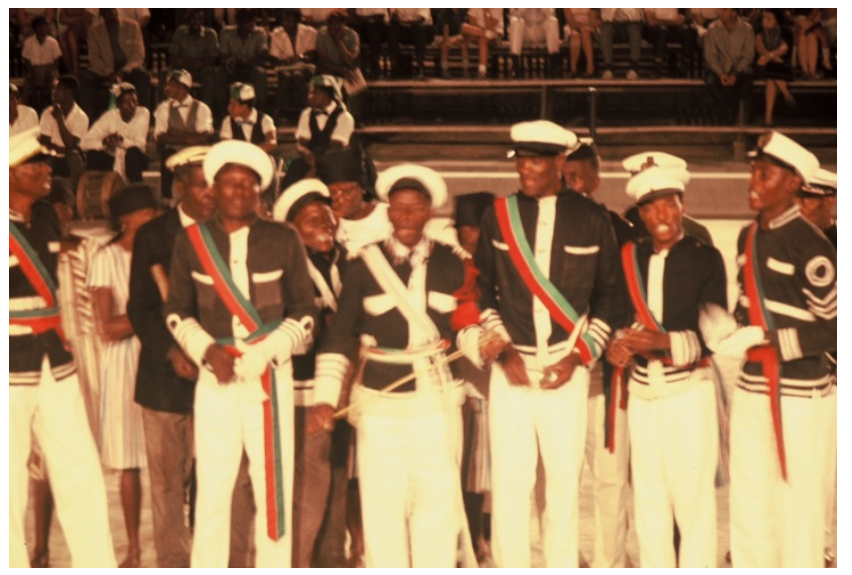

Figure 5. Some of the musicians for a Sócópé performance: As is now common, the dress is modern, rather than an approximation of what would have been worn in the $17^{\text {th }}$ century, or what was imagined to be the dress at Charlemagne's court.

\subsection{Tchíloli}

There are three major forms of São Toméan folk dance, each with its own origin and artistic requirements. The first is called Tchíloli, an obscure word in São Toméan Creole which in full signifies "The Tragedy of the Marquis of Mantua," and which is said to be derived from the cycle of the "Carlino Theater," the theme of which revolves around the life and adventures of the Emperor Charlemagne. Such plays and music-dramas were popular in Europe especially in the $16^{\text {th }}$ and $17^{\text {th }}$ centuries. The original play or plays on which São Tomé's variation rests were supposedly introduced to the island by settlers from Madéira who had come to help begin the cultivation of sugar. Traditionally, São Tomé's source play was said to have been composed by a blind Madéiran writer, Balthazar Días. 
The theme of Tchiloli concerns the murder of the nobleman Valdevinos by his friend Prince Carloto, son of the Emperor Charlemagne, during a hunt. The family of the Marquis of Mantua, to which Valdevinos belonged, sends their ambassadors to the imperial court asking for justice. [Figure 6] The Prince, who is the only heir to the throne, is protected from his father's vengeance by influential friends as well as by his mother, the Empress. Both sides, Mantuan and Imperial, then choose lawyers to argue the case before the emperor. It is in this part of the play, performed mainly in dance and pantomime, that the individual village troupes display their creativity in dance, costumes and music. [Figure 7]

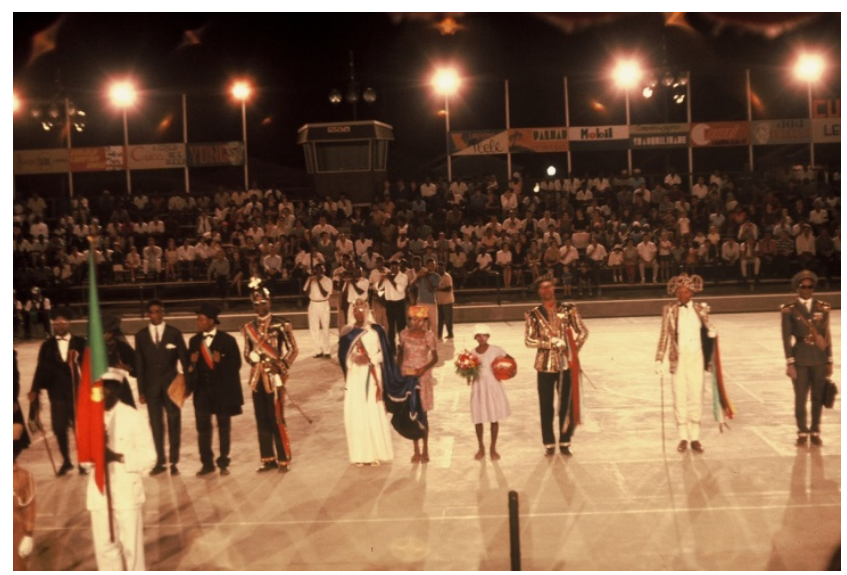

Figure 6. The court of Charlemagne in a Tchiloli performance. The Emperor is the figure at the left-center, with the white cross on the top of his crown-like hat. The Empress, in white, stands beside him, and other court officials flank the two principals. Quasi-parodies of modern dress are used; note the formal attire of the person to Charlemagne's right, and the overly-elaborate military dress of the individual, complete with attaché case, on the far right.

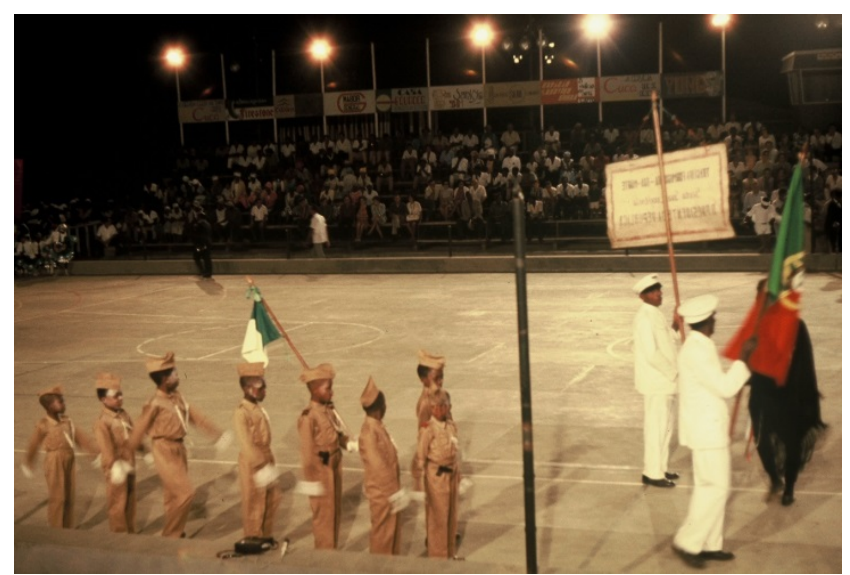

Figure 7. In the sports stadium of São Tomé, a youth group parades before a performance of Tchiloli. In the colonial era before Independence in 1975 , the Portuguese government encouraged such activities, even though tourism at the time was minimal.

After much debate, and accompanying theatrics, the Emperor condemns his son to death, and the finale of the play contains loud and violent dancing and music, representative of the tragedy of the outcome. The dialogue is supposedly the original text of Días, including anachronisms of speech, both Portuguese and Congolese, African words and phrases having been incorporated into the text over time. The style of acting, the music and, to a degree, the costumes are of African derivation (mostly Congolese and Mbundu), though older traditions, now lost, may once have been included. Tchiloli is perhaps the clearest example, in all São Toméan folk art forms, of the mixture of African and European elements in the island's culture. Though the setting is European, the basic idea of the conflict between public justice and personal desire is universal. Indeed, the theme of justice is paramount in the play as it has evolved over the centuries and is often regarded today as a critique of Portuguese colonialism, whose injustice and sometimes brutality were ever-present on pre-independence São Tomé.

Tchiloli is the most important of São Tomé's indigenous music plays. By custom, the performer of a particular role, such as that of Charlemagne, would be performed by someone for a lifetime, only giving up the role due to death or old age. In turn, the role would be passed down to a son or other close relative. Whatever the origins of this custom, it meant that expertise in performance and cultural continuity were preserved to a remarkable degree. It should also be noted that originally in Tchiloli, all roles were played by men, even the female parts. This preserves, of course, the early-modern European tradition that long kept women from the stage, as seen in the original performances of Shakespeare's plays. It also preserves the common African custom that only men could take part in public ceremonies, especially those that involved masked dancing and singing, which were often religious in nature. (Today, women and young girls are part of the performance).

A modern performance of Tchíloli can be seen on-line at $\mathrm{http}: / /$ www.youtube.com/watch? $\mathrm{v}=\mathrm{Xpr} 8 \mathrm{fL} 8 \mathrm{LGW}$.

Unlike the "official" performance photographed by the author, this takes place in a small village and is much more informal. Rather than European instruments, the music is entirely drums, wooden flutes and gourd rattles. The modernity of the dress is interesting, since one character wears a cape that is the São Tomé flag; there are also approximations of modern military uniform, and characters dressed in suits and carrying attaché cases. As is often the case in African dance, the dancers are masked (nominally, since the "mask" is thin gauze) which serves to de-personalize the actual performer and "transform" him or her into the character.

\subsection{Danço Congo}

The second major folk-dance tradition is called the Danço Congo, or the "Dance of the Captain of the Congo." Of all São Toméan folk dances, it is the one most purely African in theme and spirit, and may be derived from Congolese festivals, especially those concerning the coronation of the Mani-Kongo, (King of Kongo) carried to São Tomé by slaves in the 16th century. 
The plot concerns a man, conventionally styled the "Jester," who is unable to manage his farm. In order to have it tilled, he entrusts it to the "Captain of Congo" and his laborers, and in a short time, the latter take full possession of the farm. To celebrate their possession of the land, the laborers hold a festival to which come a "Wizard" and his "Apprentice" in secret, with the intention of killing, for some unstated reason, the son of the Jester. Their identities are discovered and they are then invited by the laborers to join the festival; instead, the pair run away to seek the help of the "Devil." [Figures 8 to 15]

Wizard, Apprentice and Devil then all dance and sing in a violent manner, placing curses on the anzo mole, or "dying angel," as the son of the Jester (Farmer) is called. Finally, the anzo mole (the name is São Tomé Creole) dies and the intruders remain in possession of the farm. Danço Congo is basically pantomime, but it is customary to improvise dialogue, commonly of an absurdly humorous and often obscene nature, which is spoken only in São Tomé Creole and unintelligible to anyone not native to the island. The music and dances of Danço Congo are the loudest, most vigorous and most violent in implication of all São Tomé folk performance art. Given its themes of theft, witchcraft and injustice, it is likely that at least some of its origins lie in a reaction to the activities and excesses of the Portuguese slave-traders in the Congo Kingdom.

A performance of Danço Congo is available at $\mathrm{http}: / / \mathrm{www}$.youtube.com/watch? $\mathrm{V}=\mathrm{dbg} 5 \mathrm{cqxdL} 70$, which was filmed in a village square and is highly informal. The central character and main dancer is the Devil, dressed in bright red, and the performance literally and figuratively revolves around him. As with the performance of Tchíloli described above, music is provided by customary instruments rather than modern ones; rattles, gourds, and some small drums accompany the dance. Modern incongruities also appear here: the Devil, while clad entirely in red, is also wearing modern gym shoes!
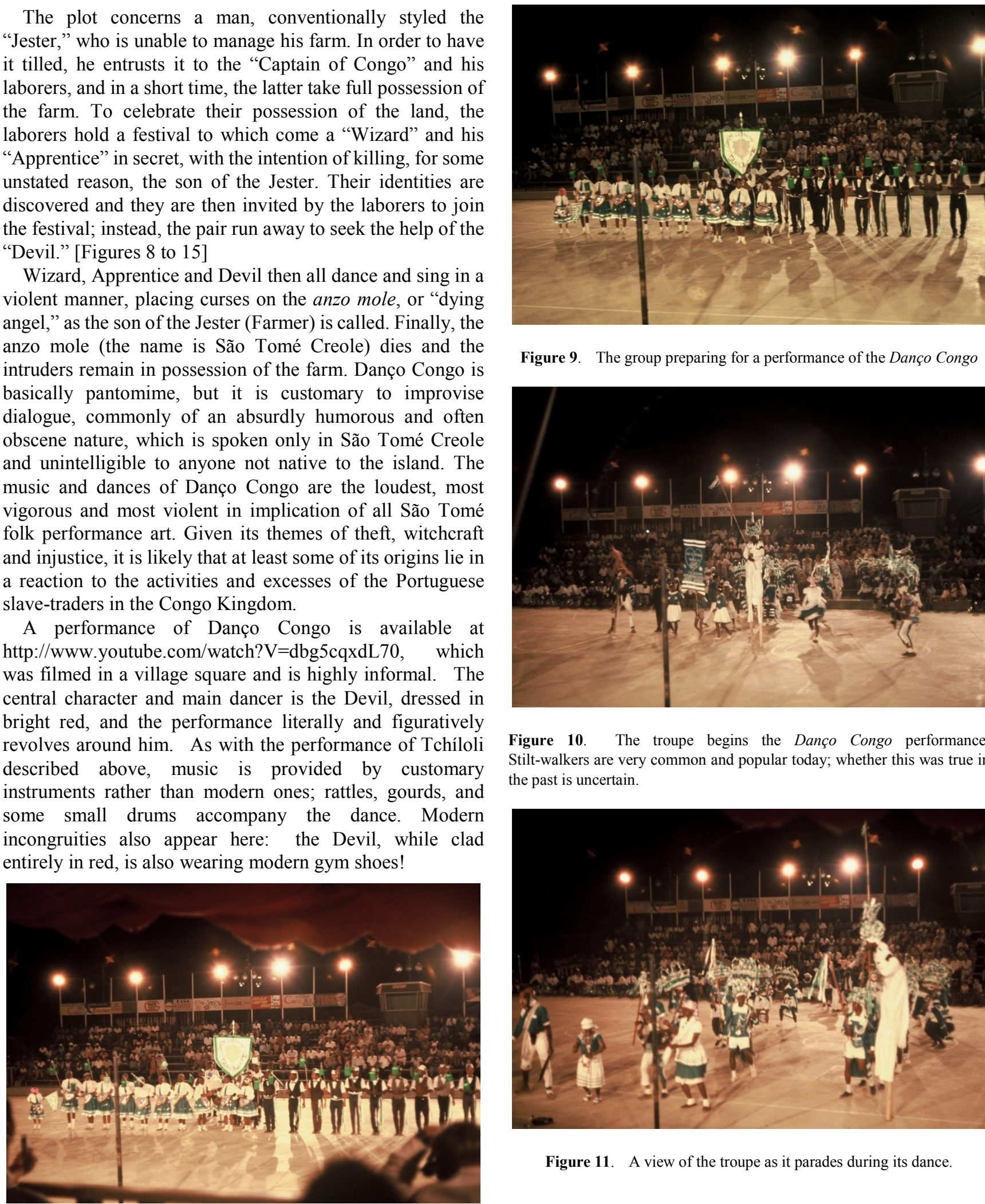

Figure 9. The group preparing for a performance of the Danço Congo

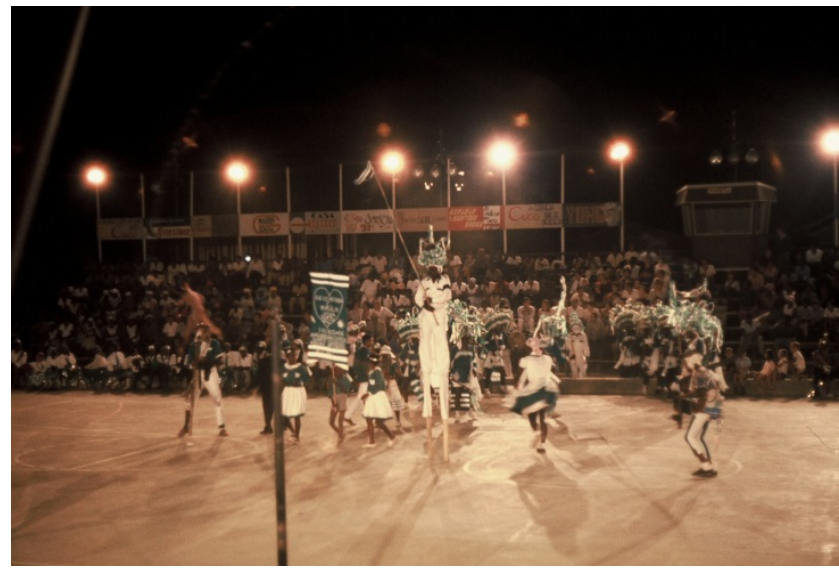

Figure 10. The troupe begins the Danço Congo performance. Stilt-walkers are very common and popular today; whether this was true in the past is uncertain.

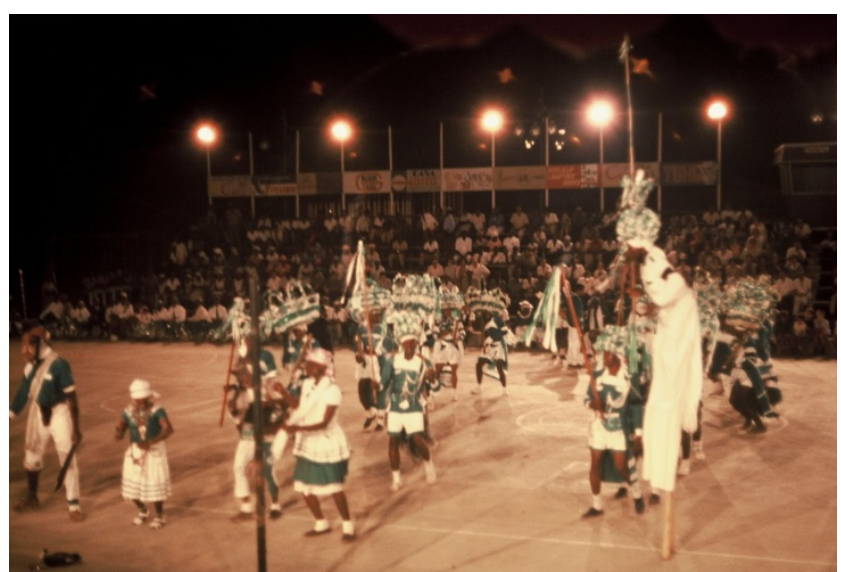

Figure 11. A view of the troupe as it parades during its dance.

Figure 8. A troupe lines up, preparing to perform the Danço Congo. The banner announces their village and association. As was common, children, even more than adults, were encouraged to take part in the performances by the colonial government. 


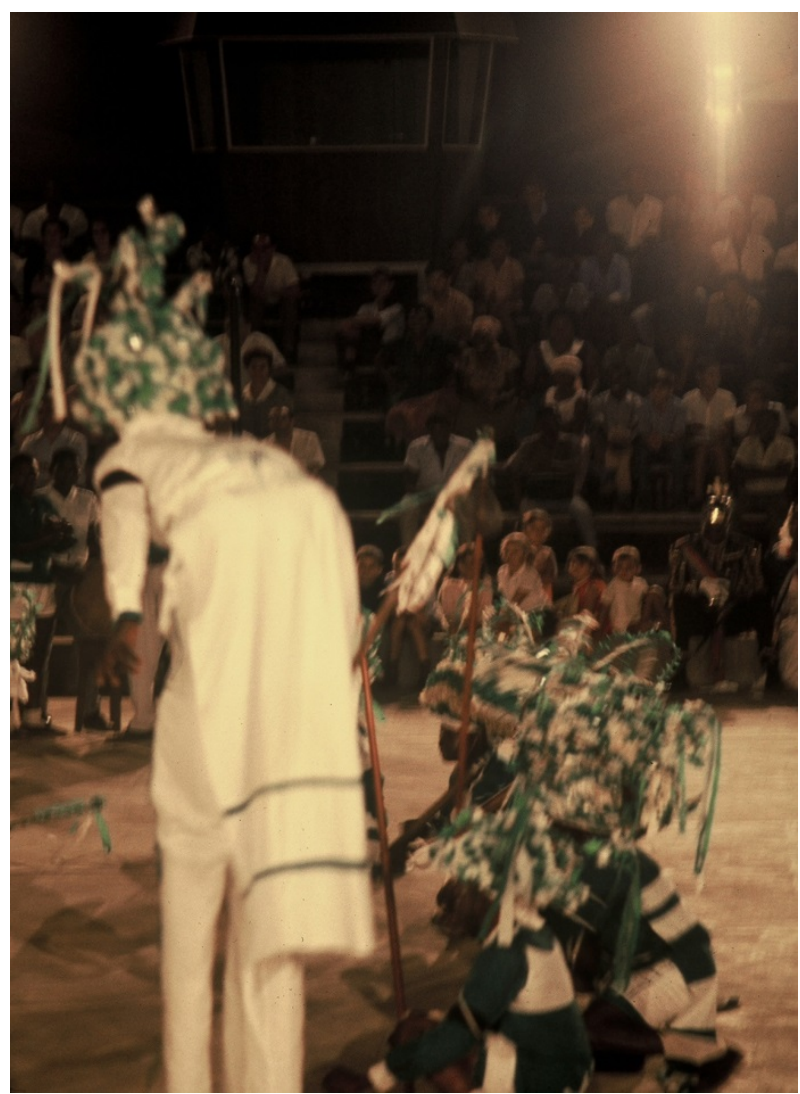

Figure 12. The stilt-walker and his co-dancers in the Danço Congo

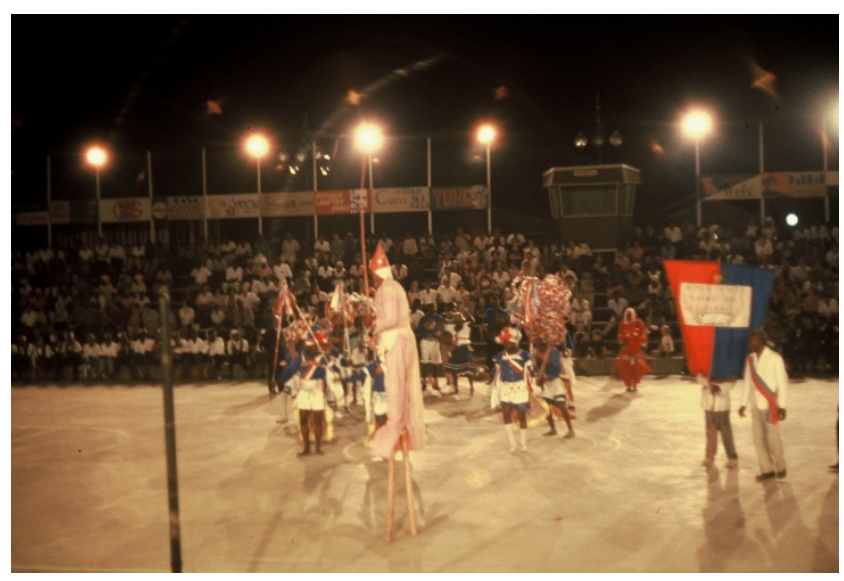

Figure 13. A second Danço Congo group performs. Differently-colored costumes identify different villages and performance groups.

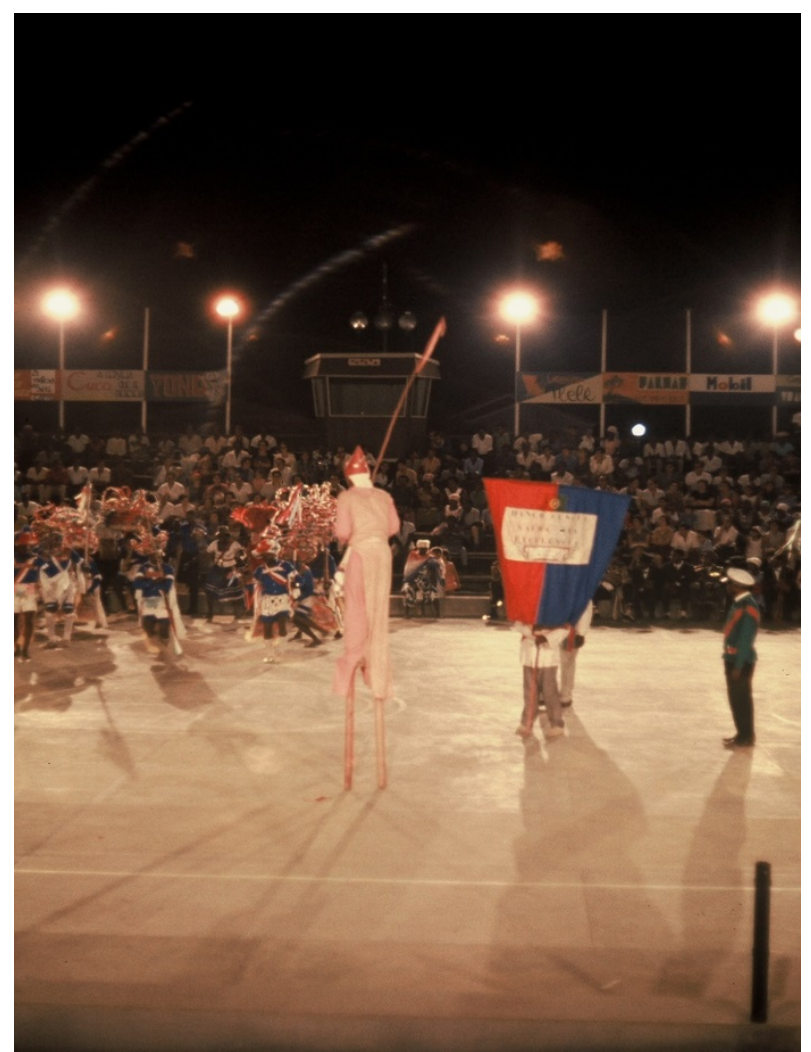

Figure 14. The stilt-walker and his co-dancers

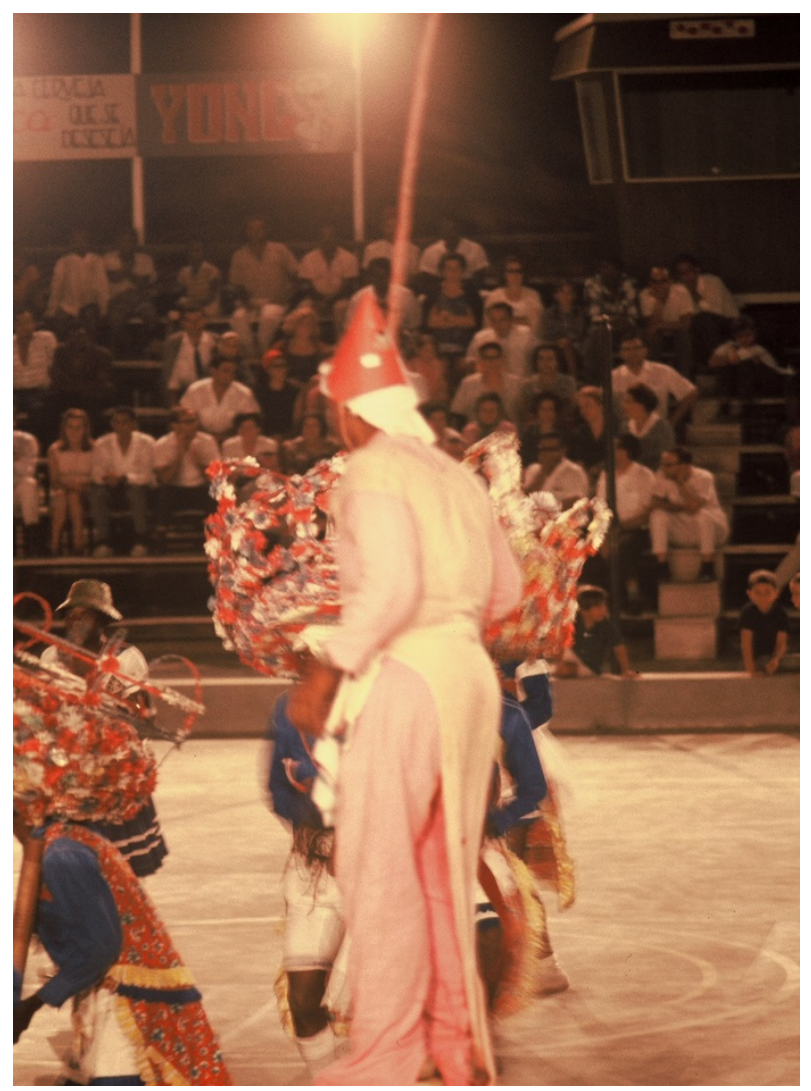

Figure 15. A close-up of the second group's stilt-walker 


\subsection{Sócópé}

The third major form of São Tomé folk dance is called Sócópé, "with only one foot." This dance is military in music, costumes and movement, resembling a staid military ball. [Figure 16] The almost-static early parts of the dance, which give the impression of almost no movement at all, give the dance its name, suggesting that the dancers move as if they had but one leg to stand on. This dance originally had no dialogue, being purely an exhibition of several modes of dancing, but it is traditional today for a speaker to deliver remarks of a comic nature between the two main parts of the dance.

The first part is slow and military, and is derived from European sources, especially the minuet. The second part is quick and lively, combining the basic slow ballroom movements with a rapid African-derived rhythm, to produce a most unusual dance effect. [Figure 17] Unlike the other two dances, Sócópé does not seem to have moral or historical implications or references, and is merely an expression of the combination of European and African art forms that has taken place on São Tomé. Sócópé is also the most recent of the dances, first appearing about 1900, thought based on an earlier dance style called the Ússua. A modern performance of Sócópé/Ússua can be seen at http://www.youtube.com/watch?v=AD82VbvEb3U which took place in São Tomé city rather than in a small village. The dance is a slow promenade through the street, partly by two separate lines of dancers, one male and one female, followed by a slow couples dance that resembles a waltz. It is performed entirely in modern dress, and in its setting and movement rather resembles a slower, low-key Mardi Gras promenade.

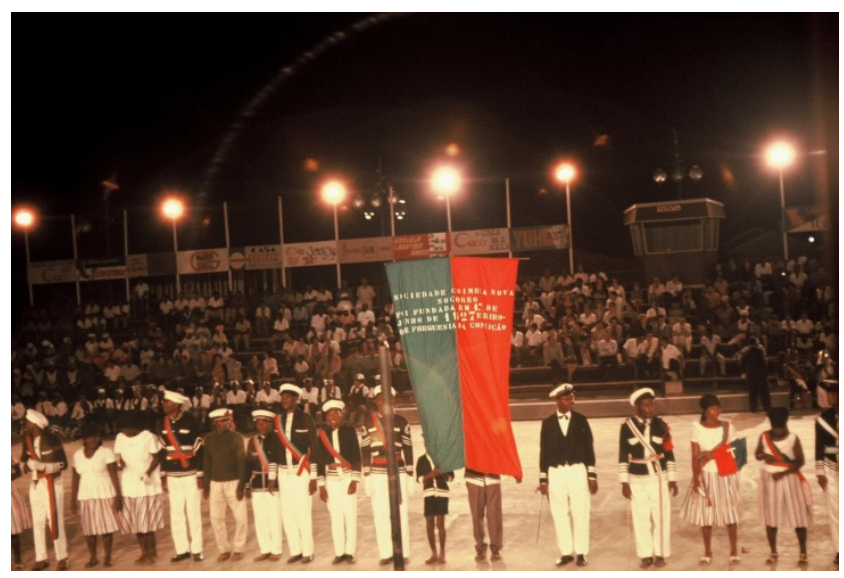

Figure 16. Sócópé marchers, with a banner showing the village and association they represent.

\section{Conclusions}

The dances of São Tomé are a blend of several traditions. Moreover, these traditions are constantly evolving. The "golden calf," whatever it may have actually been, is long gone, and rather more modern objects such as attaché cases and sunglasses have appeared. Increasingly, the dances are made for public performance, and for tourists, rather than being simply an expression of the islanders' culture created and performed only for themselves; this is clearly shown in the filmed performances referenced above, especially in the presentations of Danço Congo and Sócópé/Ússua. As São Tomé becomes increasingly involved with the outside world (a phenomenon that can only grow since the possible discovery of oil beneath the island's territorial waters, as well as greater access and facilities for tourists) we can expect that the dances will change even more; one can only imagine how the dress and morés of American oil-well drillers will show up in later versions of the dances.

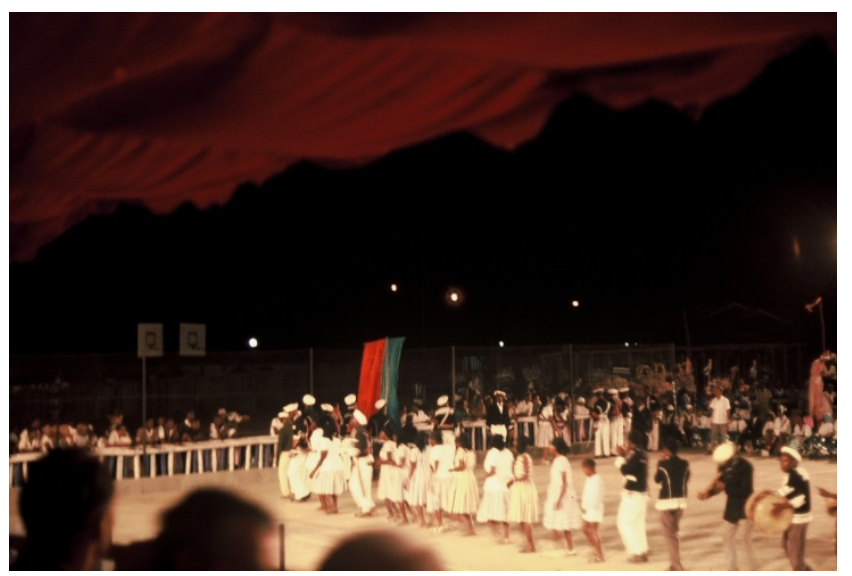

Figure 17. Sócópé performers marching

Thus, besides being an encapsulation of the island's history and culture, the changing nature of Tchiloli, Danço Congo and Sócópé serve to remind us that "folk" traditions and cultures are not merely artifacts of a static past, but reflect a community's ever-changing present and future as well.

\section{Endnotes}

[1] Tenreiro, 1961: 57-58.

[2] cf. Pereira, 1969: passim.

[3] Cunha Mattos, 1841 3, D'Eca, 1921, 37-38.

[4] Azevedo, 1921, 21 and ch. 5.

[5] Boxer, 1963:15; D’Eca, 1921, 37-38.

[6] Rosario Pinto, 1732, ch. 39; Cunha Mattos, 1841, 13.

[7] I am forever indebted to the late Sr. Antonio Luis Freitas Bastos, formerly Director of the Centro de Informação e Turísmo of São Tomé, for arranging a performance of the island's dances for me and for providing much of the information about their history and evolution, as described above. All of the photographs were made by me at the performance held in the city sports stadium,. Indulgence for the amateur nature of the pictures is humbly requested. I also wish to acknowledge the photographers who filmed the island's dances and posted them on YouTube, enabling 
anyone, anywhere, to experience the unique dances of São Tomé.

\section{REFERENCES}

[1] Azevedo, José Lucio de, Historia dos Christãos Novos Portuguésas, Livraria Classica, Lisbon, Portugal, 1921

[2] Boxer, Charles R., Race Relations in the Portuguese Empire, 1415-1825, Oxford: Clarendon Press, United Kingdom, 1963.

[3] Cunha Mattos, Raymundo José da, Corografia Historica das Ilhas de S. Tomé, Príncipe, e Fernão do Pó, Typografia da Revista, Porto, Portugal, 1841.
[4] D'Eca, Vicente, Normas Economicas nas Colonias Portuguesas até 1808, Imprensa Universitaria de Coímbra, Coimbra, Portugal, 1921.

[5] Pereira, Francisco, "O Açucar Madérense de 1500 a 1537," Insituto Superior de Ciencias de Politica Ultramarina, Lisbon, Portugal, 1969.

[6] Rosario Pinto, Manuel de, Historia da Ilha de S. Tomé, Lisbon: Ineditos Coloniais., Lisbon, Portugal, 1721.

[7] Seibert, Gerhart, Comrades, Clients and Cousins; colonialism, socialism and democratization in São Tomé and Príncipe, Brill, N.V., Leiden, Netherlands, 2006.

[8] Tenreiro, Francisco, A Ilha de S. Tomé, Lisbon: Junta de Investigações do Ultramar, Lisbon, Portugal, 1961. 